REFERENCES

Morris, H. (1938). Portrait of a Chef. Cambridge: University Press.

Soyer, A. (1 847). Charitable Cookery or the Poor Man's Regenerator. London: Simpkin Marshall \& Co. and John Ollivier.

Soyer, A. (1850). The Modern Housezife, and ed. London: Simpkin Marshall \& Co.

Soyer, A. (1854). Soyer's Shilling Cookery. London: G. Routledge \& Co.

Soyer, A. (1857a). Instructions to Military Hospital Cooks. England. Army Regulations and Orders. II. Cookery. London: H.M. Stationery Office.

Soyer, A. (1857b). Soyer's Culinary Campaign. London: G. Routledge \& Co.

\title{
Alexis Soyer and the Crimean War
}

\section{By Sir Zachary Cope, I70 Chiltern Court, Baker Street, London, N.W.I}

The three best natural doctors have for ages been known to be Doctor Quiet, Doctor Merryman and Doctor Diet. Doctor Quiet is seldom found amidst soldiers during a campaign, and Doctor Merryman does not practice on the battlefield. If the soldier is to be kept fit on active service he must depend chiefly upon Doctor Diet. Napoleon emphasized this fact when he said that an army marched upon its stomach; he took good care that his armies should feed upon the plentiful food of the land which he was invading. When, as in the invasion of Russia, the inhabitants destroyed all remaining food as they retreated, the invading army simply perished.

In the Crimean War the authorities at home and in the field either did not understand this principle or neglected to see that it was practised. Since for the first time in history there were accredited reporters who sent back vivid pictures of the breakdown of the commissariat, there was a public outcry in the newspapers at home. The harrowing descriptions printed in The Times caused Florence Nightingale to volunteer for service with the Army in October I854. On I6 January I 855 a letter appeared in The Times written by a 'Crimean' from 'before Sebastopol' in which an appeal was made for 'a receipt or two of how to concoct into a palatable shape the eternal ration of pork and biscuit which is issued to us'; the writer said that there was a public character-Alexis Soyer-who might thus do them a good turn. Six days later Soyer sent to The Times a series of recipes which could be used with the rations ordinarily served out. A week later Soyer wrote to the Government offering to go to Scutari and the Crimea at his own expense in order to help to improve the soldier's diet. Lord Panmure accepted his offer and gave him the necessary authority to make any changes that might be required. Soyer arrived at Scutari in March and he at once took counsel with Miss Nightingale, whose work in providing special diets for the sick soldiers earned his high approval. He soon made great improvements in feeding both the sick and the healthy.

To realize what he achieved one must know the conditions which he found on his arrival. His first work was at the Barracks Hospital, where there were over 2000 patients, many of them very sick men. Full diet (when it could be obtained) was adequate in food value, for it consisted of $\mathrm{I}$ lb. each of meat, bread, and potatoes, 
with 2 pt. of tea and $\frac{1}{2}$ pt. of porter. But many were on half or quarter diet. Moreover extras could only be issued to those on 'spoon' diet, which was merely I lb. of bread and 2 pt. of tea daily. Every extra diet had to be signed by the assistant surgeon and counter-signed by a senior surgeon, which with so many patients was physically impossible, and chaos ensued.

The cooks were untrained men taken from the regiments and sent back when they had just about acquired some skill by experience. The rations were not issued till 9 or Io a.m. and it was often noon or I p.m. before the meat was put into the large copper boilers where the joints were tied together in untidy manner and were very unequally cooked. The fluid in which the joints were boiled was thrown away. The meat was never boned and was served in the wards by unskilled carvers so that some patients got nothing but gristle and bone.

Within a month Soyer changed all this. He exerted his authority and obtained some skilled cooks, arranged to have the rations served earlier in the day, saw that each joint was fixed on a numbered skewer, retained the previously wasted fluid for the making of soups and introduced flavouring agents. Economy in fuelling was soon achieved by the invention of Soyer's famous stove, which is still used by the Army. This stove reduced the amount of fuel needed to less than a tenth of what had previously been necessary. Within a month of his reaching Scutari, Soyer had fixed up new kitchens and provided decent cooked diets for the majority of those in the hospitals there.

Soyer then went on with Miss Nightingale to the Crimea where conditions baffled description. The diet of those at the front had been reduced to biscuit, rum and salt pork. Soyer set up bakeries on the ships in the harbour, and subsequently he built kitchens on shore in which he provided better diet. He invented a softer type of nourishing biscuit and provided the ranks with dried vegetables made up into biscuit form so that a portion could be broken off for use when needed. His simple soups became famous and nearly everything he provided was made out of the rations normally issued. Before Soyer returned to England he was gratified to see a large number of his special stoves arrive, and he was able to demonstrate their use on a large scale.

On returning to England Soyer was soon enlisted by Miss Nightingale to help in the improvement of the kitchens in various barracks. Only a week before his death he managed to go to the Wellington Barracks to open the new and up-to-date kitchens. Miss Nightingale never threw her praise about freely, but she gave Soyer unstinted praise and regarded his death as a great disaster, for in her opinion there was no one to succeed him.

The illnesses which affected Miss Nightingale and Alexis Soyer have been loosely termed 'Crimean fever'. There is little doubt that Miss Nightingale suffered from typhus fever. A day or two before she was taken ill with her acute attack she had been warned not to stay too long talking to an officer who was ill with typhus fever, but in her usual way she had scouted the risk of infection. Her 3 weeks' illness with delirium was very like typhus fever, 
Soyer himself was attacked by diarrhoea soon after his arrival at Scutari and it lasted several weeks. In the Crimea he was taken seriously ill in September 1855; this illness lasted several weeks and when nearly well he had a relapse. The accounts given are meagre but they are more in keeping with an attack of typhoid fever. When he returned to Scutari he was again ill with fever and later with dysentery, his illness lasting 3 months. These illnesses took toll of his strength. He never again became strong. In 1858 he brought up some blood and his final illness ended in coma. The actual cause of his death is doubtful but high blood pressure is a possible diagnosis.

Alexis Soyer deserves to be remembered for his great work for the soldiers in the Crimean War.

Cook (1912), Morris (1938), O'Malley (1931) and the files of The Times for I 855 were the chief sources of my information.

\section{REFERENCES}

Cook, E. T. (1912). Life of Florence Nightingale. London: Macmillan \& Co. Ltd. Morris, H. (1938). Portrait of a Chef. Cambridge: University Press.

O'Malley, I. B. (I93 I). Florence Nightingale, I820-1856. London: Macmillan \& Co. Ltd.

\section{The human factor in hospital feeding}

By Betty R. Stanton, Dietetic and Nutritional Adviser, King Edward's Hospital Fund for London, 24 London Bridge Street, London, S.E.I

'What's the food like?' This or a similar question invariably crops up in any conversation about hospitals. Little curiosity is displayed about the prime functions of a hospital, i.e. the nursing and medical care, or indeed about the softness of the beds or other matters of general comfort. But we are all interested in food and especially when we are ill.

There is, however, a surprising lack of interest in nutrition. Sporadic and individual interest is apparent but there is no nutrition programme or policy in the hospital service, as there is in the Schools Meals Service. In the latter, both the Ministry of Education and Local Authorities recommend minimum amounts of specific nutrients to be provided by recommended quantities of foods and menus. Yet, already Stevenson \& Bensley (1947) were advocating in the Lancet 'The need for a nutritional programme in hospitals, ... made obvious by the frequency with which weight loss, representing tissue destruction, has been observed after injury and in disease. . . . Recent investigations have shown that this weight loss is due to malnutrition which may seriously interfere with recovery'.

Lack of a nutrition policy may be accounted for partly by the historical development of catering in hospitals and partly by the unique position catering holds, both in the smaller world of the hospital and the larger world of the catering industry. 